\title{
Characteristics of investors in onshore wind power in Sweden
}

\author{
Anna Darmani ${ }^{\mathrm{a}}$, Eva M.M.I. Niesten ${ }^{\mathrm{b}, *}$, Marko P. Hekkert ${ }^{\mathrm{c}}$ \\ a Department of Industrial Economics and Management, Royal Institute of Technology, 10044 Stockholm, Sweden \\ b Alliance Manchester Business School, The University of Manchester, M15 6PB, Manchester, UK \\ c Copernicus Institute of Sustainable Development, Utrecht University, 3584 CS Utrecht, The Netherlands
}

\section{A R T I C L E I N F O}

\section{Article history:}

Received 6 May 2016

Received in revised form 11 October 2016

Accepted 11 October 2016

Available online 21 October 2016

\section{Keywords:}

Firms

Dynamic capabilities

Energy policy

Wind power

Incumbents

New entrants

\begin{abstract}
A B S T R A C T
In order to facilitate the transition to electricity industries with low $\mathrm{CO}_{2}$ emissions, it is important to understand which firms invest in renewable energy technologies. This study concentrates on the heterogeneous characteristics of investors in wind power that are embedded in the investors' dynamic capabilities. Data on 617 investors in the Swedish onshore wind industry are analyzed. Investors with higher investment and management experience and a mixed generation portfolio whose business is electricity production have more assets in wind. Investors' age in the wind industry has a negative relation with assets in wind, illustrating that latecomers are investing more. Individual incumbents of the electricity industry hold a relatively large amount of assets in the Swedish wind industry, but the group of incumbents as a whole possesses only 15 percent of wind assets. The results suggest that tailor-made policies could stimulate a greater variety of firms to invest in wind power.
\end{abstract}

(c) 2016 Elsevier B.V. All rights reserved.

\section{Introduction}

To tackle the negative consequences of climate change, sustainability transitions in the electricity industry are essential. One potential approach to achieve sustainability in the electricity industry is through the adoption of renewable energy technologies and the production of Electricity from Renewable Energy Sources (RES-E). In this context, an especially promising technology is electricity production with wind turbines (GWEC, 2013). In Europe, governmental targets are set and massive investments are directed into the electricity industry to stimulate this sustainability transition (Darmani et al., 2014; Masini and Menichetti, 2013). However, the adoption rate of RES-E is still low and its share in the power generation portfolio is limited. The International Energy Agency even observes a recent slowdown in the deployment rate of solar and wind power, and concludes that this undermines the trajectory needed to decarbonize the energy supply and meet the $2{ }^{\circ} \mathrm{C}$ scenario (IEA, 2015).

To explain this slow adoption rate of RES-E, a wide body of literature shows that sustainability transitions in the electricity industry are impeded by path dependence, because we are confronted by an already-established system in the form of a fossil-fuel industry (Smink et al., 2015), profitable nuclear power generation, centralized transmission (van der Vleuten and Raven, 2006) and preexisting technologies and infrastructure (Verbong and Geels, 2010). Firms are confronted by these investment paths of the past, and hence are partially hesitant to invest in new technologies and new markets (i.e., RES-E) (Pinkse and Van den Buuse, 2012).

\footnotetext{
* Corresponding author.

E-mail address: eva.niesten@manchester.ac.uk (E.M.M.I. Niesten).
} 
In the old regulated European electricity industries, a few oligopolistic and often state-owned firms controlled the majority of these industries. However, the landscape of the electricity industries has changed after the electricity market deregulation, which allowed all types of firms to enter the industries and compete (Högselius and Kaijser, 2010). New firms entered the electricity industry with renewable energy technologies (Bergek et al., 2013; Darmani, 2015; Masini and Menichetti, 2013).

Therefore, in the current electricity industries, RES-E investors are comprised of various groups of firms, who are willing to benefit from electricity market changes. These firms play a pivotal role in the decarbonization of the electricity industry, ergo the pace of sustainability transitions in this industry. However, as yet knowledge on firms who invest in the renewable electricity industry and their heterogeneous characteristics is underdeveloped (Bergek et al., 2013; Masini and Menichetti, 2012; Wüstenhagen and Menichetti, 2012). This is problematic when plans are made about the electricity industry's future or when new policy instruments are designed. For policies aimed at stimulating RES-E investments, it is important to understand what the characteristics are of firms that invest in RES-E (Schmidt et al., 2012; Wüstenhagen and Menichetti, 2012). This understanding is especially important because still far larger investments in RES-E are needed in order to achieve the targets of the EU renewable directive (Jacobsson and Bergek, 2011).

Our study's point of departure is therefore the observation that the landscape of the electricity industry is changing, though there has been insufficient dialogue on the nature of investors who are changing this industry. This paper intends to contribute to this lack of knowledge by shedding light on the characteristics of firms that invest in wind power assets. To do so, we focus on investors' characteristics that are embedded in their dynamic capabilities, which correspond to the capability of a firm to discover, realize and exploit new opportunities in an existing or a new market (Teece, 2007; Teece et al., 1997). On the basis of this definition, the amount of dynamic capabilities determines the ability and willingness of a firm to implement changes into their processes and to respond to market changes (Lieberherr and Truffer, 2015; Penrose, 1958; Teece et al., 1997; Zahra et al., 2006).

This paper makes several important contributions to the literature. First, it combines dynamic capabilities theory and sustainability transitions literature to propose a set of characteristics of investors that invest more in wind. The identification of these characteristics allows us to highlight which investors contribute to overcoming the path dependence of the system, and are therefore more likely to contribute to transitions toward a more sustainable industry. Indeed, in both the energy and sustainability transitions literature there are arguments for benefits of applying a dynamic capabilities perspective to the energy industry (Dominguez et al., 2009; Gebauer et al., 2012; Markard et al., 2012; Worch et al., 2013), but this has seldom been done. As Markard and Truffer (2012: p. 962) highlight "the incorporation of new theoretical frameworks [e.g., capabilities-based studies and approaches] enhance the understanding of historical and ongoing sustainability transitions".

Second, this paper explains differences between the amount of wind assets of firms by empirically analyzing the relation between firms' dynamic capabilities and their assets. The majority of empirical studies that employ the dynamic capabilities perspective analyze the relation between dynamic capabilities and firm performance (Niesten and Jolink, 2015). However, several recent studies argue that dynamic capabilities are higher-order resources or routines that influence lower-order resources (e.g. wind assets) of firms, before they impact on performance (Ambrosini and Bowman, 2009; Niesten and Jolink, 2015). Research should therefore focus on studying the link between dynamic capabilities and assets of firms.

Third, this paper studies the heterogeneity of investor groups by bearing in mind that investors have different industrial backgrounds and levels of experience. Differences exist between firms' incumbency in the electricity industry and in the wind industry. The findings of this study are highly relevant for policy makers as they enable them to better understand the differences between RES-E investors and their responses to market changes. Knowing which investors are capable of and willing to contribute to sustainability changes allows for readjusting the policy mix in an effective manner.

To achieve these objectives, the case of wind power in Sweden is chosen for the empirical foundation of this paper. The results are based on data on investments in wind power by 617 firms from 1996 to 2013. In 2003, Sweden has implemented a Tradable Green Certificate (TGC) system to stimulate the integration of RES-E. Using the Swedish TGC database and by applying linear regression modeling, the paper shows which type of investors have more dynamic capabilities and build up more assets in wind power.

\section{Theoretical foundation and hypotheses}

\subsection{RES-E investors in the electricity industry}

Several drivers have been introduced into the electricity industry to increase the share of renewable energy, among which energy policy is considered the most influential (Darmani et al., 2014). Policy supports can be defined as "government policies that affect the structure and functioning of markets and the competitive advantages of its participants" (Baron, 2001, p. 47). The advantages and disadvantages of renewable energy policy for accelerating RES-E adoption have been assessed in several studies (Darmani et al., 2016; Fagiani et al., 2014; Haas et al., 2011b; Richstein et al., 2015). The results show that RES-E investors are to a large extent dependent upon favorable energy policies, and more favorable policies will in general lead to greater investments in RES-E (Haas et al., 2011a; Pettersson and Söderholm, 2009).

An emerging body of literature has started arguing that what is missing in this debate is a particular focus on the investors (Masini and Menichetti, 2013; Smink et al., 2015; Wüstenhagen and Menichetti, 2012). In this paper, investors of RES-E are identified as a heterogeneous group of actors, “... who invest in renewable electricity production rather than as actors who finance such investments, e.g. banks, funds. [. . .]. The former initiate the idea for a new plant, mobilize resources to realize it and take 
ownership of the plant once it is in place. Electricity production then becomes a part of their business" (Bergek et al., 2013, p. 573). On the basis of this definition, the role of investors in advancing RES-E is prevalent, particularly in the deregulated electricity market where the RES-E investors have the chance to make decisions based on their individual cost-benefit analyses (Laloux and Rivier, 2013). This means that RES-E investors can react in different ways to the same opportunity provided by policy changes in a market.

More recent studies have argued that these different reactions of potential investors can be explained by their heterogeneous characteristics, such as their motives (Bergek et al., 2013), experience (Bollinger and Gillingham, 2012; Drury et al., 2012; Wüstenhagen and Menichetti, 2012), investment choices (Darmani, 2015), beliefs in a technology or market efficiency (Dinica, 2006; Masini and Menichetti, 2012), risk aversion and propensity for change (Fagiani et al., 2013) and technological capabilities (Delmas and Montes-Sancho, 2011; Schmidt et al., 2012). However, there is still a need for further research on RES-E investors and their characteristics that affect their decisions for RES-E (e.g., Bergek et al., 2013; Schmidt et al., 2012). To enhance our understanding of the characteristics that lead investors to overcome the path dependence of the system, and in our case to invest in wind power, we combine the perspective of dynamic capabilities and the literature on sustainability transitions.

\subsection{Investors' dynamic capabilities and wind power assets}

Dynamic capabilities are the capabilities of firms to integrate, build and reconfigure resources, which enable firms to enter a new market (Døving and Gooderham, 2008; Eisenhardt and Martin, 2000) or to answer to market changes (Teece et al., 1997). Dynamic capabilities allow firms to overcome path dependence and to benefit from opportunities derived from changes in technologies, markets and/or customers (Vergne and Durand, 2011). They do not only represent firms' ability to change, but also their willingness to undertake such change (Teece et al., 1997; Zahra et al., 2006).

Dynamic capabilities are viewed as higher-order resources or routines that have an impact on lower-order resources (Niesten and Jolink, 2015). Examples of such higher-order resources or routines include a bundle of factors that are generally managed by firms, such as operational and managerial experiences, expertise, knowledge resources, financial reserves and production capacity (Kraatz and Zajac, 2001; Schumpeter, 1942). The word "dynamic" in the term "dynamic capability" refers to intentional changes in or renewal of lower-order resources (Ambrosini and Bowman, 2009). In this paper, the lower-order resources are the investors' assets in wind power. Firms use their dynamic capabilities or higher-order resources to invest in wind power assets.

As we argued, investors in renewable energy technologies have different characteristics, and we expect that they will also differ in terms of their dynamic capabilities. In compliance with the dynamic capabilities literature, we argue that investors with a greater amount of dynamic capabilities are more willing to adapt to electricity market changes and invest in larger amounts of wind power assets. Since dynamic capabilities are difficult (or even impossible) to measure directly (Niesten and Jolink, 2015), we use a set of proxies that are in line with other studies (Rothaermel and Deeds, 2006). This paper measures an investor's dynamic capabilities by its investment experience, management experience, industrial background and generation portfolio. In addition, we explore the relationship between firms' incumbency and their amount of wind power assets building on both the sustainability transition literature and dynamic capabilities literature. The following sections will illustrate the relation of these characteristics of investors to the assets in wind.

\subsubsection{Investment experience of investors}

Dynamic capabilities are higher-order resources or routines by which firms achieve new resource configurations (Eisenhardt and Martin, 2000). These higher-order resources or routines are built up by experience. Teece et al. (1997, p. 521) discuss that "the capacity to reconfigure and transform is itself a learned organizational skill. The more frequently practiced, the easier accomplished".

On the basis of an extensive review of the literature, Ambrosini and Bowman (2009) state that dynamic capabilities are typically the outcome of experience. Zollo and Winter (2002) mention that dynamic capabilities arise from the repeated execution of similar tasks and experience accumulation, and King and Tucci (2002, p.171) argue that "generating such capabilities requires enough experience". With experience, a firm can augment its process implementation in a changing market environment (Zollo and Winter, 2002) and such a learning process allows a firm's activities to be "performed more effectively and efficiently as an outcome of experimentation, [thus] reflecting on failure and success" (Ambrosini and Bowman, 2009, p. 35).

Drawing on these studies, we use experience as a proxy for dynamic capabilities, which is also in line with other empirical studies in the field (Rothaermel and Deeds, 2006). In our study, investment experience reflects the higher-order routines to decide on the location of new wind turbines, to choose the capacity of wind turbines, and to manage the production of wind power. We measure investment experience by recording the number of years in which the firm has invested in new wind power capacity. The investment experience is assumed to determine a firm's level of dynamic capabilities and therefore have a positive impact on its amount of wind power assets. Hence,

Hypothesis 1: An investor's investment experience in the wind industry positively affects its amount of technological assets in wind power. 


\subsubsection{Management experience of investors}

The dynamic capabilities literature also draws attention to the importance of management experience in building up dynamic capabilities (Rindova and Kotha, 2001; Zahra et al., 2006). To capture a firm's management experience this paper recognizes that managers gain experience through different ventures, and we measure management experience as the number of firms that one investor manages concurrently in the wind industry. This is based on the assumption that a manager can improve firm processes in a systematic and predictable fashion, using his experiences. Such improvements in firm processes reflect a higher level of dynamic capabilities.

More specifically, management experience develops the higher-order routines that enable firms to manage among others the human resources and administrative side of new firms, such as hiring new employees and keeping track of new regulations on wind power. Previous research has shown that managers involved in the ownership of multiple businesses accumulate experience and they leverage this experience to identify subsequent investment opportunities (Ucbasaran et al., 2009). In our case, management experience enables firms to identify new opportunities and invest in wind power assets.

While we do expect to observe a positive relation between management experience (as a proxy for dynamic capabilities) and wind power assets, we also propose that this relation will level off at a certain number of businesses, and decrease after that. Previous research has shown that there exists an inverse U-shaped relation between business ownership experience and opportunity identification (Ucbasaran et al., 2009). One reason for this relation is that managers are likely to be prone to information-processing overload (Rothaermel and Deeds, 2006). If they manage too many businesses, they are not able to identify new opportunities and expand in new companies, and in our case, in new wind power assets. We therefore formulate the following hypothesis in this study:

Hypothesis 2: There will be an inverse U-shaped relation between an investor's management experience in the wind industry and its amount of technological assets in wind power.

\subsubsection{Industrial background and generation portfolio of investors}

The dynamic capabilities literature explains that a firm needs to create, change or renew its resources in order to maintain its competitive advantage in a changing market environment (Teece et al., 1997). Firm's resources are partly dependent on the industry in which the firm is located (Musiolik et al., 2012). Therefore, this paper assumes that one way of accessing new resources is by joining new industries.

In this context, authors such as $\mathrm{Ng}$ (2007) make a distinction between strong form and weak form dynamic capabilities to identify the extent to which a firm modifies its resources. In the strong form dynamic capabilities, a firm can introduce new resources without being constrained by its prior knowledge of resource uses, and therefore the firm expands its resources into new as well as unrelated fields (Ng, 2007). Having strong form dynamic capabilities, firms enter markets that necessitate a set of new resources and make decisions independent of their historical processes (Eisenhardt and Martin, 2000).

In this study, an example of strong form dynamic capabilities are the firms that invest in the renewable energy market, but have a different industrial background, such as in the agricultural or real-estate industries. These firms with a different industrial background aspire to search for a new market by broadening their range of products and services, and by gaining knowledge about electricity market legislation. These firms must utilize their dynamic capabilities to invest in wind power assets. Hence, in this paper, we study strong form dynamic capabilities by analyzing whether firms from another industry make more investments in wind power. ${ }^{1}$ Therefore,

Hypothesis 3: An unrelated industrial background of an investor in the wind industry positively affects its amount of technological assets in wind power.

On the other hand, weak form dynamic capabilities draw on a firm's prior knowledge of resource uses to reveal new uses from its existing resource bundle, and these are therefore associated with expanding its resources into related fields ( $\mathrm{Ng}$, 2007). Døving and Gooderham (2008) show that firms with dynamic capabilities expand their business into related services, and are able to generate an important proportion of their revenue from these services. Expanding a firm's resources into related fields is used as a tool for effective deployment of all the firm's resources, the use of its specific capabilities, and to ascertain its strategic direction and reduce redundancies (Penrose, 1958; Zahra and Nielsen, 2002; Zahra et al., 2006).

In the case of the electricity industry, it is expected that investors in wind power who also invest in other types of renewable energy to utilize their weak form dynamic capabilities. These firms benefit from their knowledge, such as on market legislation, competition, and resources in the electricity industry, to exploit the available opportunities in this industry. In this paper, weak form dynamic capabilities are therefore studied by measuring whether firms that invest in wind power also have investments in other types of renewable energy, such as solar power, hydropower or biomass (i.e., mixed generation portfolio). Therefore,

Hypothesis 4: A mixed generation portfolio of an investor in the wind power industry positively affects its amount of technological assets in wind power.

\footnotetext{
${ }^{1}$ While different industries may require different levels of diversification capabilities in order to invest in the wind power industry (e.g., farmers vs. municipalities investing in wind assets), this study only distinguishes between electricity producers and others. This is because an analysis of the "level of diversification capabilities' requires extensive analysis of industrial competences, which are outside of this study's scope.
} 
Electricity Industry

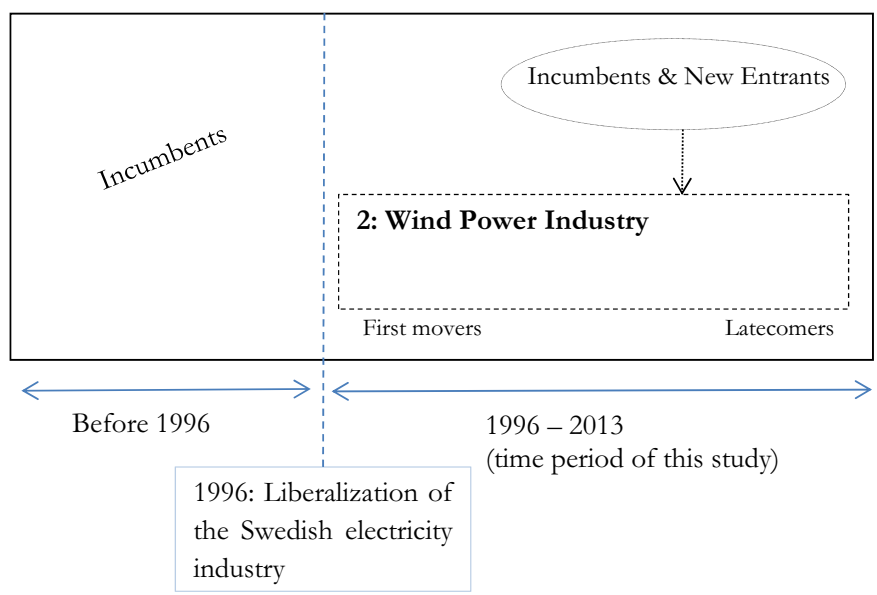

Fig. 1. Incumbents and new entrants in the electricity industry \& first movers and latecomers in the wind power industry.

\subsubsection{Incumbency of investors in the electricity and wind power industry}

The literature on sustainability transitions has argued that firms, depending on their incumbency status, may have very different perspectives on new technologies that promote sustainability in an industry (Geels, 2014). These firms may therefore hold a different amount of assets in the sustainable technologies. In this paper we examine the relation between firms' incumbency (the timing of investments) and their amount of wind assets. In order to provide a more detailed analysis, we study firm's incumbency at two different levels: the electricity industry and the wind power industry.

At the electricity industry level, we distinguish between incumbents and new entrants based on the time that they found a chance to join the electricity industry. In this paper, incumbents are the oligopolistic firms of old regulated electricity industries, while new entrants are the players who only joined the electricity industry after the European electricity industry liberalization (i.e. after 1996). Fig. 1 shows that before 1996 the electricity industry consisted only of incumbents, but after 1996 the industry is made up of incumbents and new entrants.

The sustainable transitions literature argues that incumbents resist transitions towards low-carbon electricity systems (Geels, 2014), and new entrants are the ones that introduce sustainable energy innovations (Smink et al., 2015). The main argument for these differences is that incumbents have vested interests in the existing system, while new entrants stand to benefit from change towards new technologies. Incumbents have often made substantial investments in the existing technology, which makes them at least partially hesitant to invest in new technologies (Pinkse and Van den Buuse, 2012). In the case of the electricity industry, the dominant role of incumbents in a strong fossil fuel regime inhibits them from changing to a more sustainable technology (Bosman et al., 2014). This is in line with the dynamic capabilities perspective, which has also argued that firms with established market positions have fewer incentives for exploiting new market opportunities (King and Tucci, 2002; Teece et al., 1997). Following this existing literature, we expect that incumbents in the electricity industry invest less in wind power when compared to new entrants. Therefore,

Hypothesis 5: Incumbents have a lower amount of technological assets in wind power when compared to new entrants.

We also examine firms' incumbency at the wind power industry level, and distinguish between the two groups of first movers and latecomers. First movers are firms that invest early in wind power, from 1996 onward (see Fig. 1), while latecomers invest closer to the end of our study period (i.e. closer to 2013). The sustainability transitions literature has argued that first movers provide positive external economies to follower firms in that they make visible new business opportunities and reduce uncertainties (Bergek et al., 2008). We therefore expect that latecomers invest more than first movers, and consequently that latecomers (i.e., younger firms) in the wind power industry invest more in wind. Therefore,

Hypothesis 6: An investor's age in the wind power industry negatively affects its amount of technological assets in wind power.

Fig. 1 shows that in the liberalized environment both the incumbents and new entrants may decide to invest in wind power at different points in time. This means that the incumbents or new entrants can be among the first movers or latecomers. Therefore, the analyses at the two distinct levels allow us to determine whether incumbents are first movers or latecomers in the new technology. Results are discussed in detail in Section 4.

\section{Method and data}

\subsection{Case selection: Sweden}

We selected the case of onshore wind power in the Swedish electricity industry as the empirical context of our paper. The selection of Sweden is based on the deregulation, regulatory changes and transparency of the Swedish electricity industry. 


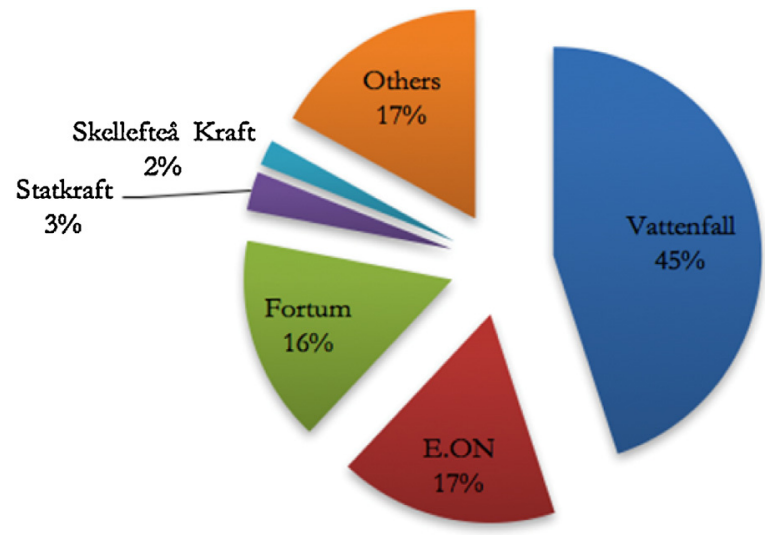

Fig. 2. Market shares of the largest electricity power producers in Sweden in 2013 (Ei, 2014).

The figure includes the names of the five producers; and the percentages refer to the market share of each producer and of the remaining smaller firms in the industry.

\subsubsection{Deregulation of the Swedish electricity industry}

The Swedish electricity industry has been liberalized since 1996, and thus allows for competition between investors, regardless of their size and position (Högselius and Kaijser, 2010). In the reports of the Council of European Energy Regulators (CEER) and the European Commission, electricity companies are considered as "main" producers when they produce at least $5 \%$ of national net electricity production. In Sweden these companies are Vattenfall, Fortum, E.ON, Statkraft and Skellefteå Kraft (CEER, 2010; European Commission, 2011). All of these companies have been established in the Swedish electricity industry before the liberalization, and still have sizable market shares (see Fig. 2). These firms can be classified in the category of incumbents at the electricity industry level. ${ }^{2}$ We classify the other firms in our database as new entrants. It could be the case that some of the investors in the latter category are old and big players in other industries, yet are not incumbents of the Swedish electricity industry. As shown in Fig. 2, the incumbents own around $83 \%$ of the Swedish electricity industry in 2013, while the new entrants (others) have a $17 \%$ share.

\subsubsection{Regulatory changes in the Swedish electricity industry}

In Sweden, there have been a few yet significant variations in the national regulatory framework for renewable energy over time. The main regulatory change is the introduction of a TGC system in May 2003. In the TGC system RES-E producers receive a certificate for every MWh of their electricity production. In Sweden, all types of RES-E (i.e., wind, solar, hydro, and biomass power) are eligible for the same level of subsidies (i.e., certificates), meaning that the TGC system is technologyneutral. The certificate can be sold in a market where the price is determined based on supply and demand. To stimulate the demand for certificates, the government obligates that a quota of sold or consumed electricity of certain parties to be from RES-E (Darmani et al., 2016).

Fig. 3 shows that the number of wind power plants (purple bars) and the installed capacity of wind power (red line) display a similar trend as the certificate prices (two blue lines, with and without a 2-year time lag). ${ }^{3}$ We statistically analyzed the relation between the average certificate price and number of registered wind plants annually from 1996 to 2013, to have a more precise overview of the relation between energy policies and investments in wind power. This analysis confirmed the relation and indicated a significant relation with a 2-year time lag, generating an $\mathrm{R}^{2}$ of $62.1 \%$ significant at $0.01 \%$ level. It demonstrates that the growth in wind assets is linked to changes in the regulatory framework and confirms that energy policy is an important determinant of investment in wind assets.

The TGC system is thus a technology-neutral system that stimulates investments in a variety of renewable energy sources. The consistent use of this program over time allows us to study the attributes of investors without large interferences of exogenous parameters.

\subsubsection{Transparency of the Swedish electricity industry}

The Swedish energy agency endeavors to create transparency by publishing a database of the RES-E plants that receive certificates for their electricity production. The selected database has been used in earlier research (e.g., Bergek et al., 2013; Darmani, 2015) and is used in this paper, because it offers representative data on investments in onshore wind power in Sweden.

\footnotetext{
2 These five firms are the incumbents of the Swedish electricity industry, rather than the Swedish renewable electricity industry.

3 Since all the energy produced in wind power plants is used for the generation of electricity in Sweden, all of the installed capacity is eligible for receiving certificates.
} 


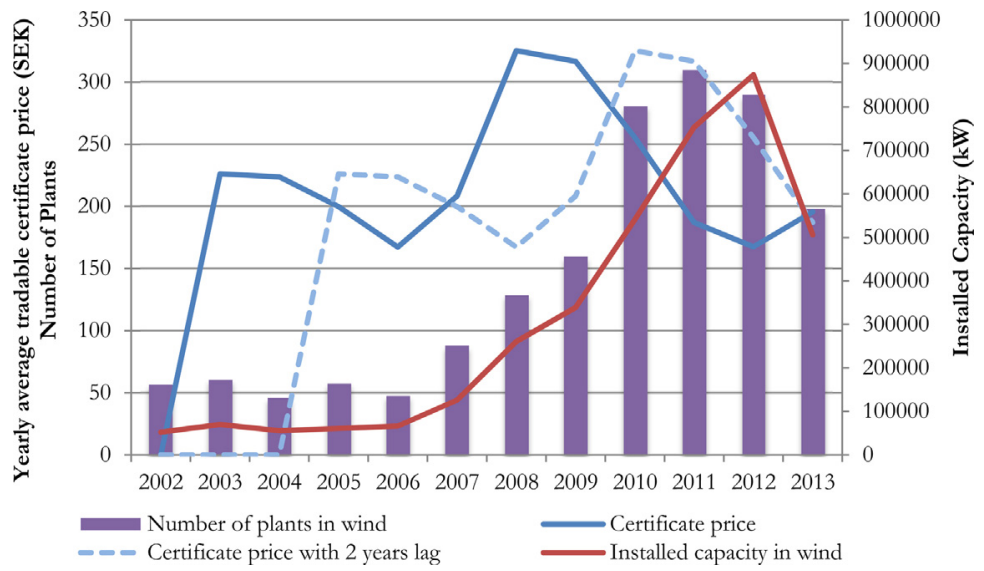

Fig. 3. Installed capacity and registered number of plants in onshore wind power market vs. average tradable certificate price (Source: Swedish tradable certificate database and www.skm.se).

All the figures presented in this paper only illustrate the population of plants that received certificates for their RES-E production, instead of the whole population of plants.

\subsection{Data and operationalization of variables}

The Swedish TGC database encompasses data on registered onshore wind power plants in Sweden from 1983 to $2013 .^{4}$ In Sweden two groups of plants have been issued certificates. The first group includes the plants that were constructed before 2003. These plants were promised certificates until 2012-2014, depending on whether they had already received any governmental supports. The second group comprises the plants that were constructed after 2003 and are guaranteed certificates for 15 years. The data on onshore wind power plants for this study are restricted to the time span 1996-2013. ${ }^{5}$ The year 1996 with initiation of the Swedish electricity industry liberalization is considered as the starting point.

The Swedish TGC database provides a snapshot of all the plants that are approved to receive certificates at a certain point in time. Until the end of 2013, in Sweden there was only one major phase-out at the end of 2012 during which 1400 plants were removed from the system. As confirmed by the Swedish Energy Agency, all the phase-outs before that year are negligible. Accordingly, for the analyses in this paper we combined 2 versions of the Swedish TGC database: the database published on all the active plants in the system at the end of 2013 and the database published at the end of 2012 on all the phased-out plants from the system.

This includes a total number of 617 firms during the time span under study. The database includes information on the name of the plant, its capacity and yearly production, the owner(s), organizational number of the owner(s), type of electricity sources, first date of commissioning and (or) capacity expansion, electricity region and state. Note that the theoretical framework of this paper applies to firms and accordingly the unit of analysis in this study is the firm. For our study organizational number is used as a reference to distinguish among firms. ${ }^{6}$

Additional data on each plant's owner are obtained from an additional data source, namely the official website of www.allabolag.se. ${ }^{7}$ Through this website information on the firms' registration date, partnership status and CEO (i.e., manager) in the Swedish company's registration office (Bolagsverket) is extracted. Furthermore, information on the industry in which the firm is involved is also found on www.allabolag.se. The primary Swedish Industrial Code $\left(\mathrm{SNI}^{8}\right)$ for each firm is recorded to capture the firm's industry. This means that if a firm is active in several industries, we only focused on the firm's primary industry. To classify the industrial background of investors, we counted the number of firms that are active in each industry. Provided that the number of firms in an industry was more than three, we classified that industry as a separate category (see Fig. 4). Industries with less than 3 firms are included in the category of 'others'. Note that all the incumbents in the Swedish energy industry are electricity producers, but the new entrants have diversified industrial backgrounds (see Fig. 4).

\footnotetext{
${ }^{4}$ We ran the statistical analyses only on onshore wind power plants and excluded offshore wind power plants. This was to eliminate the effects of the outlier data caused by different specifications (e.g., size, capacity, location) of onshore and offshore wind power plants. Only four firms invested in Swedish offshore wind power.

${ }^{5}$ The database includes data on plants that have been installed or expanded, but does not include information on exits from the market.

${ }^{6}$ The database includes data on private persons that invest in RES-E, but does not mention names or registration numbers for this group of investors. Due to this lack of data and the focus of the theoretical framework on firms, we have excluded private persons from the analysis.

7 The website belongs to a service agency that gathers business information on all the Swedish companies. The agency collects data from the Swedish Companies Registration Office (Bolagsverket), Tax Agency (Skatteverket) and Statistics Sweden (SCB). According to the KIA index - the official measurement index for Swedish websites - the Allabolag website is the most acknowledged information service for those who need information about firms.

${ }^{8}$ For further information please refer to http://www.sni2007.scb.se/.
} 


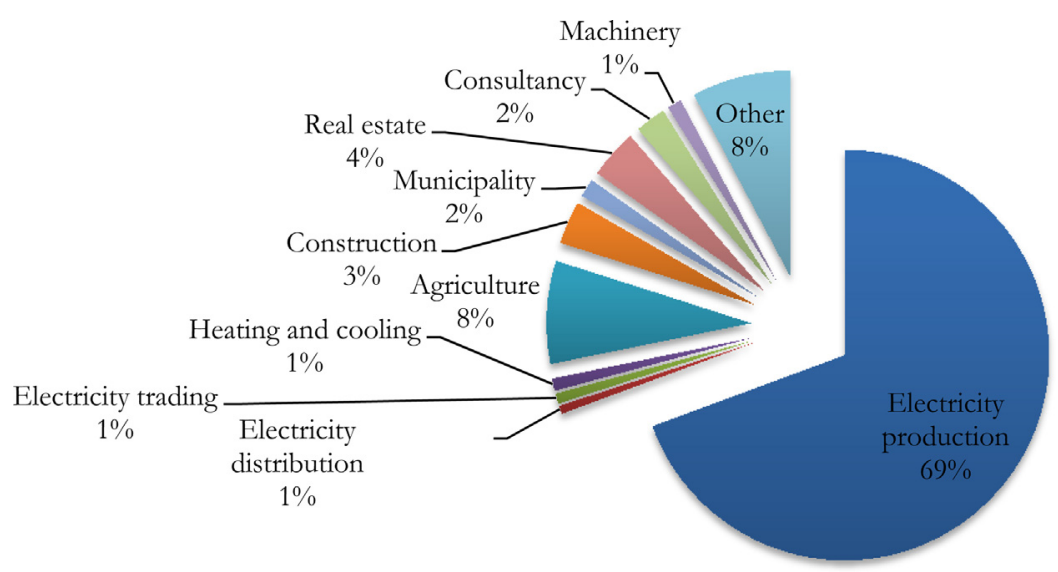

Fig. 4. Taxonomy of wind power investors' industry (Source: Own elaboration from Swedish tradable certificate database and www.allabolag.se).

Lastly, we recorded the legal form of the firms in our database, also taken from the website www.allabolag.se. Our findings show that $85 \%$ of the firms are Limited Companies, and the remaining $15 \%$ have 12 different types of legal form.

This study requires measures of one dependent variable, 6 independent variables and 3 control variables, all of which are presented below.

\subsubsection{Dependent variable}

Technological assets of an investor in wind are measured by recording cumulative installed capacity $(\mathrm{kW})$ for each investor at the end of the year 2013.

\subsubsection{Independent variables}

Investment experience of a firm is captured by the total number of years in the time span under study in which a firm has made investments.

Management experience is measured by extracting the name of the CEO for each firm and identifying the CEOs who manage more than one firm at a time. Thus, the number of firms managed by the same CEO is used to measure experience of a firm's manager. Provided that a management board instead of one CEO managed a firm, the number is calculated for each member of that board and the maximum number is used to present the management experience of the firm. This number ranges from 1 to 16 firms. We also include the squared term of management experience to test whether there is an inverse U-shaped relation between this variable and the amount of assets in wind power.

Industrial background is defined as a binary variable, making a distinction between wind power investors whose primary industry is electricity production (coded as 1 ) and those whose primary industry is not electricity production (coded as 0 ).

Generation portfolio taps into the number of renewable energy technologies in which an investor has made an investment, with 1 indicating only wind and 2, 3, or 4 indicating a mixed generation portfolio (hydro, solar and/or biomass).

Incumbent in the electricity industry is defined as a binary variable where the five incumbents identified in Fig. 2, and three firms of which the parent company is one of the incumbents are coded as 1 (=8 firms) and new entrants, which are coded as 0 , are all the other firms in our dataset (=609 firms).

Age of investor within the wind power industry is captured by subtracting the first year that a firm has installed capacity in the wind industry from the last year of analysis (2014).

\subsubsection{Control variables}

We introduce three control variables for alternative possible explanations, namely firm age, parent company and number of invested regions.

Firm age is calculated by extracting the firm's registration date in the Swedish Companies Registration Office from the last year of analysis (2014). $(=0)$.

Parent company is a binary variable, which differentiates between firms with a parent company $(=1)$ and firms without

Number of invested regions is measured by counting the number of municipalities in which the firm has made an investment. In Sweden, different municipalities have different permission processes for the establishment of wind power plants. At present, Sweden has 290 distinguished municipalities, as is shown in Fig. 5. 


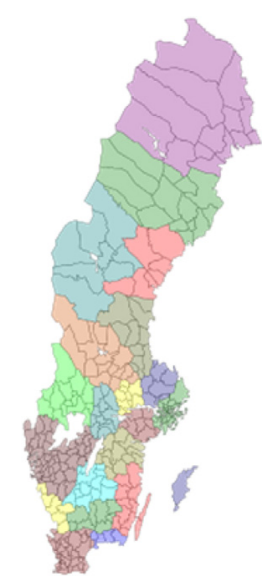

Fig. 5. Municipalities of Sweden.

\subsection{Data analysis}

Our model with technological assets as the dependent variable and nine independent and control variables was estimated using OLS. The model was run on the onshore wind power plants, which have received certificates, from 1996 to 2013. Nevertheless, we considered that there is a possibility of incomplete entries in the TGC database between 1996 and 2003 (before the initiation of the TGC system). Also, motivations, numbers or industrial profiles of firms before and after the introduction of the Swedish TGC framework could have changed significantly. In order to cope with these issues, we also ran the analysis on firms that have joined the Swedish onshore wind industry after 2003 and until 2013. This time period includes 413 firms. The analyses yielded the same results and confirmed the reliability of our data (see Table 2).

In spite of our efforts, we have missing data for a few variables that are gathered from other data sources. The number of missing values, however, is considered as minimal (indicated in Table 2) as far as making a difference in the analysis. We use list-wise deletion to cope with the missing values in our dataset, which reduces the number of observations to 590 for the period 1996-2013 and 396 for the period 2003-2013.

We performed a Durbin-Watson test to test for the possible presence of autocorrelation in the model residuals. The results confirmed the assumption of independent errors (Field, 2013). We also checked for multicollinearity and obtained VIF and tolerance scores on the relation between the independent and control variables. Bowerman and O'Connell (1990) suggest that VIF substantially different from 1 and greater than 10 implies a problem in the variables. The VIF values range between 1.12 and 3.45 in the model between 1996 and 2013, and between 1.25 and 2.41 in the model between 2003 and 2013 , indicating that there is no multicollinearity problem in our data.

\section{Results}

\subsection{Model results and descriptive statistics}

Table 1 presents the descriptive statistics and pairwise correlation matrix. Table 2 presents the results of three different models. Model 1 includes only the control variables. Model 2 is the complete model including both control and independent variables for the analysis from 1996 to 2013. Model 3 shows the results for the time period 2003-2013. The $\mathrm{R}^{2}$ of model 2 and 3 is substantially higher than the $\mathrm{R}^{2}$ of Model 1 . The characteristics of investors recorded in Model 2 explain about $42 \%$ of the variation in the dependent variable (i.e. assets in wind power). In social science studies, $\mathrm{R}^{2}$ above $20 \%$ is assumed to be valid for studying relations between different variables (Hair et al., 1995; Mei et al., 2013).

With respect to Hypothesis 1 , the results show that investment experience positively and significantly influences the assets in wind. When a firm has 1 year more experience with investing, its assets in wind increase by $6302 \mathrm{~kW}$. To understand the importance of firms' investment experience (measured by number of investment years), we compared wind assets of firms who invest in several plants in different years, with firms who invest in larger but limited numbers of plants. The result showed that firms who own smaller plants, yet invest more frequently, have a higher share of wind assets, providing evidence on the importance of firm's investment experience. We also find evidence for Hypothesis 2 . We observe an inverse U-shaped relation between management experience and wind assets. When managers coordinate up until four firms concurrently, the results show a positive effect on wind assets. However, when managers have five or more firms, we observe a negative relation with wind assets. Managing more than four firms at the same time has limited the manager's capabilities to explore emerging 
Table 1

Mean, standard deviation and correlations of variables in model 2.

\begin{tabular}{|c|c|c|c|c|c|c|c|c|c|c|c|c|c|c|}
\hline & & Number & Mean & St. dev & 1 & 2 & 3 & 4 & 5 & 6 & 7 & 8 & 9 & 10 \\
\hline 1 & Technological asset (kW; in onshore wind power) & 617 & 6023.349 & 14193.21 & 1.000 & & & & & & & & & \\
\hline 2 & Investment experience & 617 & 1.319 & 0.956 & $0.433^{*}$ & 1.000 & & & & & & & & \\
\hline 3 & Management experience & 590 & 1.928 & 2.648 & $0.117^{*}$ & -0.007 & 1.000 & & & & & & & \\
\hline 4 & Industrial background & 590 & 0.693 & 0.461 & $0.139 *$ & 0.034 & -0.032 & 1.000 & & & & & & \\
\hline 5 & Generation Portfolio & 617 & 1.030 & 0.207 & 0.154 & 0.122 & -0.043 & -0.088 & 1.000 & & & & & \\
\hline 6 & Incumbent in the electricity industry & 617 & 0.012 & 0.113 & $0.430^{*}$ & $0.216^{*}$ & $-0.019^{*}$ & 0.076 & $0.121^{*}$ & 1.000 & & & & \\
\hline 7 & Age of investor within the wind power industry & 617 & 8.709 & 5.836 & -0.135 & $0.278^{*}$ & $-0.178^{*}$ & -0.068 & 0.165 & -0.009 & 1.000 & & & \\
\hline 8 & Firm age & 617 & 14.628 & 13.973 & -0.003 & $0.150^{*}$ & $-0.155^{*}$ & $-0.388^{*}$ & $0.306^{*}$ & 0.053 & $0.035^{*}$ & 1.000 & & \\
\hline 9 & Parent company & 617 & 0.304 & 0.460 & $0.255^{*}$ & 0.077 & 0.350 & -0.087 & 0.088 & $0.173^{*}$ & -0.066 & 0.053 & 1.000 & \\
\hline 10 & Number of invested regions & 617 & 1.223 & 0.984 & $0.375^{*}$ & $0.830^{*}$ & 0.001 & 0.018 & 0.001 & $0.221^{*}$ & $0.185^{\circ}$ & $0.121^{*}$ & 0.078 & 1.000 \\
\hline
\end{tabular}

Significant at 0.01 level. 
Table 2

Model results on investor characteristics and investments in wind power.

\begin{tabular}{|c|c|c|c|c|c|c|c|c|c|}
\hline \multirow[t]{2}{*}{ Variable } & \multicolumn{3}{|c|}{ Model 1 (617 firms) (Control variables) } & \multicolumn{3}{|c|}{ Model 2 (590 firms) (All variables: 1996-2013) } & \multicolumn{3}{|c|}{ Model 3 (396 firms) (All variables: 2003-2013) } \\
\hline & $\begin{array}{l}\text { Std. } \\
\text { Error }\end{array}$ & $\begin{array}{l}\beta \\
\text { Std. } \beta\end{array}$ & Sig & $\begin{array}{l}\text { Std. } \\
\text { Error }\end{array}$ & $\begin{array}{l}\beta \\
\text { Std. } \beta\end{array}$ & Sig & $\begin{array}{l}\text { Std. } \\
\text { Error }\end{array}$ & $\begin{array}{l}\text { B } \\
\text { Std. } \beta\end{array}$ & Sig \\
\hline (Constant) & 979.657 & -1684.918 & 0.086 & 2725.612 & $-11562.540^{*}$ & 0.000 & 5900.744 & $-24681.010^{*}$ & 0.000 \\
\hline Investment experience & & & & 872.451 & $\begin{array}{l}6302.455^{*} \\
0.424^{*}\end{array}$ & 0.000 & 1740.174 & $\begin{array}{l}9400.090^{*} \\
0.341^{*}\end{array}$ & 0.000 \\
\hline Management experience & & & & 653.112 & $\begin{array}{l}2320.714^{*} \\
0.424^{*}\end{array}$ & 0.000 & 829.1074 & $\begin{array}{l}3020.073^{*} \\
0.631^{*}\end{array}$ & 0.000 \\
\hline Management experience square & & & & 40.277 & $\begin{array}{l}-134.4041^{*} \\
-0.388^{*}\end{array}$ & 0.001 & 49.906 & $\begin{array}{l}-178.813^{*} \\
-0.603^{*}\end{array}$ & 0.000 \\
\hline Industrial background & & & & 1110.128 & $\begin{array}{l}3031.688^{*} \\
0.095^{*}\end{array}$ & 0.007 & 1619.440 & $\begin{array}{l}4209.615^{*} \\
0.123^{*}\end{array}$ & 0.010 \\
\hline Generation portfolio & & & & 2386.65 & $\begin{array}{l}7775.15^{*} \\
0.109^{*}\end{array}$ & 0.001 & 5770.063 & $\begin{array}{l}17999.44^{*} \\
0.147^{*}\end{array}$ & 0.002 \\
\hline $\begin{array}{l}\text { Incumbent in the electricity } \\
\text { industry }\end{array}$ & & & & 4178.934 & $\begin{array}{l}37270.53^{*} \\
0.297^{*}\end{array}$ & 0.000 & 5591.203 & $\begin{array}{l}16087.96^{*} \\
0.131^{*}\end{array}$ & 0.004 \\
\hline $\begin{array}{l}\text { Age of investor within wind power } \\
\text { industry }\end{array}$ & & & & 90.689 & $\begin{array}{l}-622.666^{*} \\
-0.248^{*}\end{array}$ & 0.000 & 238.054 & $\begin{array}{l}-1263.766^{*} \\
-0.242^{*}\end{array}$ & 0.000 \\
\hline Firm age & 37.088 & $\begin{array}{l}-61.179 \\
-0.06\end{array}$ & 0.100 & 40.768 & $\begin{array}{l}31.141 \\
0.029\end{array}$ & 0.445 & 70.696 & $\begin{array}{l}52.330 \\
0.039\end{array}$ & 0.46 \\
\hline Parent company & 1120.141 & $\begin{array}{l}7095.812^{*} \\
0.230^{*}\end{array}$ & 0.000 & 1105.579 & $\begin{array}{l}3812.971^{*} \\
0.122^{*}\end{array}$ & 0.001 & 1585.669 & $\begin{array}{l}4443.003^{*} \\
0.138^{*}\end{array}$ & 0.005 \\
\hline $\begin{array}{l}\text { Number of invested } \\
\text { regions } \\
\mathrm{R}^{2}\end{array}$ & 527.2549 & $\begin{array}{l}5263.829^{*} \\
0.365^{*} \\
0.196\end{array}$ & 0.000 & 822.772 & $\begin{array}{l}-429.058 \\
-0.029 \\
0.421\end{array}$ & 0.602 & 2004.945 & $\begin{array}{l}90.399 \\
0.002 \\
0.357\end{array}$ & 0.964 \\
\hline Adjusted $\mathrm{R}^{2}$ & & 0.192 & & & 0.411 & & & 0.340 & \\
\hline
\end{tabular}

${ }^{*} \mathrm{P}<0.01$. 


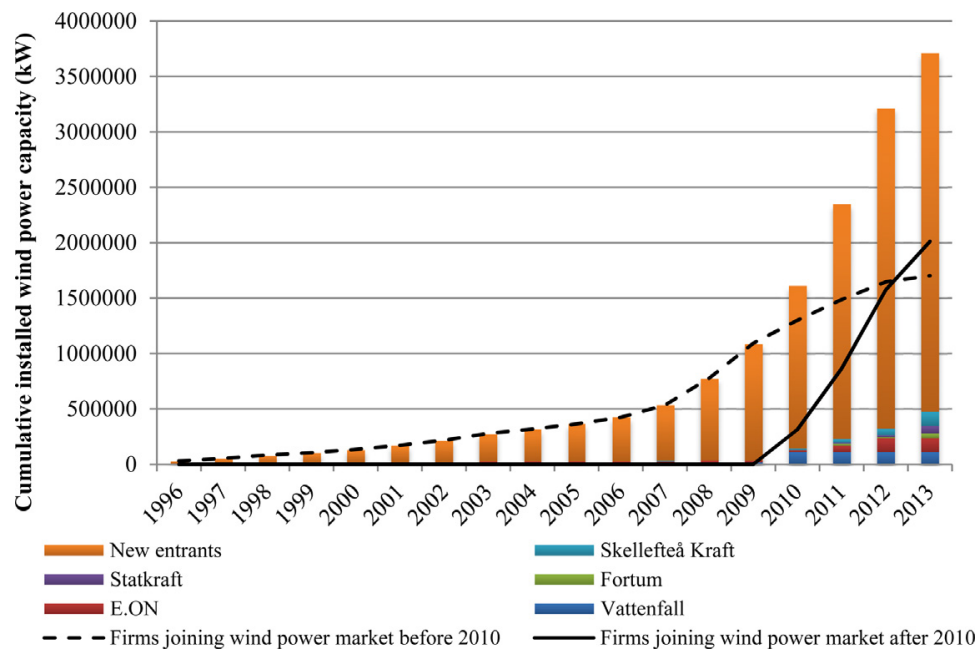

Fig. 6. Cumulative installed wind power capacity of incumbents and new entrants from 1996 to 2013 (Source: Own elaboration from Swedish tradable certificate database).

In Fig. 6 for calculating cumulative installed wind power capacity of each incumbent, we accumulated the assets of each incumbent and all its sub-firms, in accordance with the measurement method used for the variable incumbent in the electricity industry.

opportunities. A manager may not spot these opportunities, because of limited access to information or over-confidence in his own experience and judgments (Brailey et al., 2001).

Hypothesis 3 is not confirmed. We cannot conclude that an unrelated industrial background of investors, as a proxy for their strong form dynamic capabilities, leads to higher assets in wind. In contrast, the positive significant result shows that firms that center their activities on electricity production invest more in wind assets. The availability of electricity producers' complementary resources (e.g., knowledge of the electricity system, network connection and access to human capital) may explain this result.

The results confirm Hypothesis 4, and we can conclude that the investors' mixed generation portfolios, representing their weak form dynamic capabilities, have a positive and significant effect on wind assets. Firms that invest in other types of renewable energy, such as solar, biomass or hydropower, in addition to wind power, have a greater amount of assets in wind when compared to firms with less mixed generation portfolios. This implies that investors, who are more capable of reconfiguring their existing resources, are more responsive to the changes in the electricity industry towards sustainability.

The results also show that if a firm is an incumbent, it holds a higher share of wind assets, when compared to a new entrant at the electricity industry level. Therefore, we cannot confirm Hypothesis 5. However, Hypothesis 6 is confirmed and the results show that a latecomer invests more in wind assets than a first mover. We observe a significant and negative relation between firm age in the wind industry and investments in wind assets. This suggests that latecomers in the wind industry exploit emerging market opportunities more.

The regression analyses provide insights into the relation between the attributes of an individual investor and its wind assets. To complement these analyses, we also offer an overview of the changes in the market shares of the group of incumbents versus the group of new entrants, and the group of latecomers versus the group of first movers. Fig. 6 maps the annual market shares of incumbents and new entrants (the bars); as well as the shares of first movers and latecomers (the lines, for investors joining the market before or after 2010 as an example). Fig. 6 illustrates that the capacity of wind power increases on an annual basis and that the group of new entrants own the majority of the wind industry. The share of the group of incumbents in the wind industry was only about $29 \%$ in 1996 , at its lowest level of only $4 \%$ in 2009 , and in 2013 less than $15 \%$. This means that the group of new entrants has always owned a majority of the Swedish wind industry (85\% of the market share in 2013 based on the TGC database). Fig. 6 also shows that incumbents make considerable investments in wind assets between 2010 and 2013. Being among the latecomers in the Swedish wind power industry, incumbents have managed to possess individually and on average a higher share of wind assets than individual new entrants as the results of our regression analyses show.

Two of the control variables were identified as insignificant in Model 2, implying no relation between firm age and number of regions on the one hand and firms' wind assets on the other hand. While younger firms in the wind industry (i.e. latecomers) are more likely to have more assets, we cannot conclude that about the general age of firms. The control variable partnership status of firms has a positive and significant relation with wind assets. In subsection 4.2 further discussions on this variable and its potential effect on the results of our model are provided.

Overall, our results have identified a series of relationships between investor characteristics that are embedded in their dynamic capabilities and the firms' amount of wind assets. The model results indicate that investors with a greater investment experience, a greater management experience (between 1 and 4 firms), an industrial background in producing electricity, 
and that hold a mixed generation portfolio have a higher amount of wind assets. Moreover, the results reveal that firms who have joined the wind industry in more recent years invest more in wind assets. The incumbents of the electricity industry have started to invest late in wind assets, and are therefore latecomers in the Swedish onshore wind industry.

\subsection{Robustness of the results}

As explained in the method section, to ensure the robustness of our results we also ran Model 3 for investments in the period 2003-2013. The results of Model 3 are reported in Table 2 and are in line with the findings of Model 2.

Model 2 demonstrated the significant contribution of firms with an industrial focus on electricity production to the amount of wind assets. As an additional robustness test, we separated our dataset into two subsets: one set containing only firms with business in electricity production, and another set containing only firms with no industrial background in electricity production. We ran our model on these two subsets of the data, and the results were the same as the results of Model 2. For instance, the results illustrated that firms with a mixed generation portfolio and a background in electricity production have higher wind assets, and firms with a mixed generation portfolio and no background in electricity production also have higher wind assets.

In another test, we used an alternative proxy for investment experience to determine whether the impact of experience on our dependent variable remains the same across different specifications. As opposed to the number of years in which firms invest, we have also used the number of plants in which firms invest as a proxy for experience. The results (direction of the effect and significance) are similar for the two proxies and for model 2 and 3.

Furthermore, the results of Model 2 indicated that firms who have a parent company have a higher amount of wind assets. In the Swedish wind industry firms may open a new production sub-firm for a new wind power plant. Therefore, this paper takes a closer look at the parent company of the firms under study to check the robustness of our results. Our analysis indicated that in the database 188 firms (out of 617) have a parent company. The parent companies consisted of 148 distinct companies. The majority of the parent companies only own one firm in the Swedish wind power industry (131 firms out of 188). However, we also found 13 parent companies owning more than one firm during the time span under study (ranging from 2 to 13 firms). This means that only a few firms are subsidiaries of the same parent company. We ran three additional tests. In the first test, we excluded all the firms whose parent company owns more than one firm and ran the analyses on all the other firms ( 560 firms). In the second test, we ran the model only on firms with a parent company (188 firms). In the last test, we merged all the sub-firms that have the same parent company and ran the model on the whole database (573 firms). The results of all the tests were in line with the findings of Model 2 and Model 3.

\section{Discussion}

\subsection{Conclusion}

On the basis of an empirical study of 617 wind power investors in Sweden, we identified various attributes of investors and determined which investors invest more in wind. In line with the dynamic capabilities perspective, we show that investors invest more in wind when they have a greater investment experience gained through more frequent investments as opposed to one-off large investments. Also, results show that investors with a greater management experience up until the management of four firms hold a higher amount of wind assets. These findings contribute to the emerging research agenda that argues for establishing links between the dynamic capabilities and assets of firms.

In addition, the results show that investors that have industrial backgrounds in electricity production and possess mixed generation portfolios have higher amounts of wind assets. In line with the expectations of the sustainability transitions literature, this paper reveals that firm age in the wind industry has a negative and significant influence on wind assets. This suggests that latecomers are investing more in wind power. Incumbents have started to invest more in wind power in the years 2010-2013, and invest on average more than the average new entrant. Due to these more recent investments, the incumbents of the electricity industry are latecomers in the wind industry. However, the share of the group of incumbents in the wind industry in 2013 is still very small (15\%) when compared to the share of the group of new entrants (85\%).

\subsection{Policy implications}

In the context of a homogeneous policy framework, our paper has shown that different types of investors exist, and that some investors invest more in wind than others. The main policy implication derived from this finding is that as an alternative to a homogeneous policy framework (as is implemented in the Swedish industry), more policies tailor-made for heterogeneous investor groups should be fostered. Our statistical analysis provides evidence of investors' heterogeneity in terms of their industrial background, experience levels and incumbency status. We offer several suggestions to implement tailor-made policies for investors that do not have substantial investments in a homogeneous policy environment. First, a tailor-made policy can support the engagement of non-energy based firms (e.g. agricultural or real-estate) in the wind industry by giving them additional financial incentives. Second, the policy can increase the knowledge- and experience-level of firms by disseminating information on the wind industry and technology for investors with less experience. Third, it can 
motivate incumbents to contribute to the renewable energy industry, for example by obliging them to keep a balanced market share in the renewable and non-renewable energy markets.

Actual examples of tailor-made renewable energy policies are the Dutch SDE policy ${ }^{9}$ and the German legal framework (EEG 2.0). ${ }^{10}$ Both policies stimulate the production of renewable energy, while offering different levels of subsidy for different types of technologies and amounts of generated renewable energy. The German policy provides higher subsidies for smaller investments (i.e., capacity size) supporting investments of particular investor groups such as households or farmers. The SDE subsidy scheme changes over time, by altering the level of subsidies available for different renewable technologies and by adding renewable energy technologies that are eligible for the subsidies. For instance, since 2011 and 2012 respectively green gas hubs and renewable heat are allowed to apply for subsidies, ${ }^{11,12}$ which has attracted different types of investors such as waste incineration companies or farmers with fermentation plants. This illustrates that tailor-made policies have the ability to target and attract specific types of investors.

Previous studies have also suggested the use of tailor-made policies, for instance, Wüstenhagen and Menichetti (2012, p. 6) argue for an "ambidextrous policy. . in which a combination of tailor-made policies simultaneously address the 'greening' of incumbents and support the emergence of new entrepreneurial competitors." However, to understand which tailor-made policies would work more effectively for different types of investors further empirical research is required.

\subsection{Limitations and future research}

This paper is among a few first studies that quantitatively analyze firms investing in RES-E, and yet due to its scope as well as data availability partly bounded in its findings. Therefore, it is noteworthy to acknowledge the limitations of this study, while simultaneously proposing directions for future research. First, there are other important characteristics, such as growth ambitions, operational capability, profitability, size of firms, and managerial education, that this research did not investigate, but that may have an impact on investments in wind power. Second, it is important to explore firms' investment motives, for instance if their related or unrelated industrial background motivates or allows them to build skills that are useful for their investment in wind power. Third, with respect to the empirical foundation in this study, we only focused on investors active in the Swedish wind power market. Testing the findings of this paper in other countries and by adding more predictor variables in future studies would be worthwhile. Fourth, although we provided insights into parent companies of the studied firms, we did not analyze their characteristics. Fifth, in order to measure investor characteristics, we had to make a number of assumptions, based on the existing theory and data availability. For example, we measured management experience of a firm by recording the number of firms that the firm's CEO directs concurrently. Revenue or number of employees of the firm could be another measure. The number of investment years is used as a proxy for investment experience, but the number of plants or projects could be an alternative. Further analysis and measurement methods can extend the findings of this study.

\section{Acknowledgements}

This research was conducted within the framework of the European Doctorate in Industrial Management (EDIM). This doctorate program is funded by The Education, Audiovisual and Culture Executive Agency (EACEA) of European Commission under Erasmus Mundus Action 1 programs. Also, the authors acknowledge the opportunity provided by Eu-SPRI association for collaboration between the two universities, Royal Institute of Technology, Sweden, and Utrecht University, The Netherlands.

\section{References}

Ambrosini, V., Bowman, C., 2009. What are dynamic capabilities and are they a useful construct in strategic management? Int. J. Manage. Rev. 11, 29-49. Baron, D.P., 2001. Theories of strategic nonmarket participation: majority-rule and executive institutions. J. Econ. Manage. Strat. 10, 47-89.

Bergek, A., Jacobsson, S., Carlsson, B., Lindmark, S., Rickne, A., 2008. Analyzing the functional dynamics of technological innovation systems: a scheme of analysis. Res. Policy 37, 407-429.

Bergek, A., Mignon, I., Sundberg, G., 2013. Who invests in renewable electricity production? Empirical evidence and suggestions for further research. Energy Policy 56, 568-581.

Bollinger, B., Gillingham, K., 2012. Peer effects in the diffusion of solar photovoltaic panels. Marketing Sci. 31, 900-912.

Bosman, R., Loorbach, D., Frantzeskaki, N., Pistorius, T., 2014. Discursive regime dynamics in the Dutch energy transition. Environ. Innov. Soc. Trans. 13, $45-59$.

Bowerman, B.L., O’Connell, R.T., 1990. Linear Statistical Models: An Applied Approach. PWS-Kent Publishing Company.

Brailey, K., Vasterling, J.J., Franks, J.J., 2001. Memory of psychodiagnostic information: biases and effects of expertise. Am. J. Psychol. 114, 55.

CEER, 2010. The Swedish Electricity and Natural Gas Markets 2010. Energy Markets Inspectorate R2011:09, Sweden.

Døving, E., Gooderham, P.N., 2008. Dynamic capabilities as antecedents of the scope of related diversification: the case of small firm accountancy practices. Strateg. Manage. J. 29, 841-857.

\footnotetext{
${ }^{9}$ www.rvo.nl/sites/default/files/2016/08./Brochure\%20SDE\%202016\%20openstellingsronde\%20najaar.pdf.

10 www.cleanenergywire.org/dossiers/eeg-20-new-legal-framework-german-energy-transition-0.

11 www.rvo.nl/sites/default/files/Jaarbericht\%202011\%20SDE+\%20SDE\%20en\%20MEP\%20[kleurenversie].pdf.

12 www.rvo.nl/sites/default/files/2014/06./Rapportage\%20hernieuwbare\%20energie\%202013.pdf.
} 
Darmani, A., Arvidsson, N., Hidalgo, A., Albors, J., 2014. What drives the development of renewable energy technologies? Toward a typology for the systemic drivers. Renew. Sustain. Energy Rev. 38, 834-847.

Darmani, A., Rickne, A., Hidalgo, A., Arvidsson, N., 2016. When outcomes are the reflection of the analysis criteria: a review of the tradable green certificate assessments. Renew. Sustain. Energy Rev. 62, 372-381.

Darmani, A., 2015. Renewable energy investors in Sweden: a cross-subsector analysis of dynamic capabilities. Util. Policy $37,46-57$.

Delmas, M.A., Montes-Sancho, M.J., 2011. US state policies for renewable energy: context and effectiveness. Energy Policy 39, $2273-2288$.

Dinica, V., 2006. Support systems for the diffusion of renewable energy technologies-an investor perspective. Energy Policy $34,461-480$.

Dominguez, D., Worch, H., Markard, J., Truffer, B., Gujer, W., 2009. Closing the capability gap: strategic planning for the infrastructure sector. Calif. Manage. Rev. 51, 30.

Drury, E., Miller, M., Macal, C.M., Graziano, D.J., Heimiller, D., Ozik, J., Perry IV, T.D., 2012. The transformation of southern California's residentia photovoltaics market through third-party ownership. Energy Policy 42, 681-690.

Ei, 2014. The Swedish Electricity and Natural Gas Markets 2013. Ei R2014:18 Energimarknadsinspektionen, Sweden.

Eisenhardt, K.M., Martin, J.A., 2000. Dynamic capabilities: what are they? Strat. Manage. J. 21, 1105-1121.

European Commission, 2011. Sweden Energy Market.

Fagiani, R., Barquín, J., Hakvoort, R., 2013. Risk-based assessment of the cost-efficiency and the effectivity of renewable energy support schemes: certificate markets versus feed-in tariffs. Energy Policy 55, 648-661.

Fagiani, R., Richstein, J.C., Hakvoort, R., De Vries, L., 2014. The dynamic impact of carbon reduction and renewable support policies on the electricity sector. Utilities Policy 28, 28-41.

Field, A., 2013. Discovering Statistics Using IBM SPSS Statistics. Sage.

GWEC, 2013. Global Wind Report: Annual Market Update 2013. Global Wind Energy Council.

Gebauer, H., Truffer, B., Binz, C., Störmer, E., 2012. Capability perspective on business network formation: empirical evidence from the wastewater treatment industry. Eur. Bus. Rev. 24, 169-190.

Geels, F.W., 2014. Regime resistance against low-carbon transitions: introducing politics and power into the multi-level perspective. Theory Cult. Soc. (0263276414531627).

Högselius, P., Kaijser, A., 2010. The politics of electricity deregulation in Sweden: the art of acting on multiple arenas. Energy Policy 38, $2245-2254$.

Haas, R., Panzer, C., Resch, G., Ragwitz, M., Reece, G., Held, A., 2011a. A historical review of promotion strategies for electricity from renewable energy sources in EU countries. Renew. Sustain. Energy Rev. 15, 1003-1034.

Haas, R., Resch, G., Panzer, C., Busch, S., Ragwitz, M., Held, A., 2011b. Efficiency and effectiveness of promotion systems for electricity generation from renewable energy sources-lessons from EU countries. Energy 36, 2186-2193.

Hair, J.F., Black, W.C., Babin, B.J., Anderson, R.E., Tatham, R.L., 1995. Multivariate Data Analysis, 4th ed. Prentice-Hall, Englewood Cliffs, NJ.

IEA, 2015. Energy Technology Perspectives 2015 - Mobilising Innovation to Accelerate Climate Action, Paris.

Jacobsson, S., Bergek, A., 2011. Innovation system analyses and sustainability transitions: contributions and suggestions for research. Environ. Innov. Soc. Trans. 1, 41-57.

King, A.A., Tucci, C.L., 2002. Incumbent entry into new market niches: the role of experience and managerial choice in the creation of dynamic capabilities. Manage. Sci. 48, 171-186.

Kraatz, M.S., Zajac, E.J., 2001. How organizational resources affect strategic change and performance in turbulent environments: theory and evidence. Org. Sci. 12, 632-657

Laloux, D.N., Rivier, M., 2013. Technology and operation of electric power systems. In: Ignacio, J., Pérez-Arriaga (Eds.), Regulation of the Power Sector., pp. $1-46$.

Lieberherr, E., Truffer, B., 2015. The impact of privatization on sustainability transitions: a comparative analysis of dynamic capabilities in three water utilities. Environ. Innov. Soc. Trans. 15, 101-122.

Markard, J., Raven, R., Truffer, B., 2012. Sustainability transitions: an emerging field of research and its prospects. Res. Policy $41,955-967$.

Masini, A., Menichetti, E., 2012. The impact of behavioural factors in the renewable energy investment decision making process: conceptual framework and empirical findings. Energy Policy 40, 28-38.

Masini, A., Menichetti, E., 2013. Investment decisions in the renewable energy sector: an analysis of non-financial drivers. Technol. Forecast. Social Change 80, 510-524.

Mei, M.Q., Laursen, K., Atuahene-Gima, K., 2013. Learning to innovate: how does ambidextrous learning matter to radical and incremental innovation capabilities? 35th DRUID Celebration Conference 2013, 17-19.

Musiolik, J., Markard, J., Hekkert, M., 2012. Networks and network resources in technological innovation systems: towards a conceptual framework for system building. Technol. Forecast. Social Change 79, 1032-1048.

Ng, D.W., 2007. A modern resource based approach to unrelated diversification. J. Manage. Stud. 44, 1481-1502.

Niesten, E., Jolink, A., 2015. The impact of alliance management capabilities on alliance attributes and performance: a literature review. Int. J. Manage. Rev. 17, 69-100.

Penrose, E.T., 1958. The Theory of the Growth of the Firm. Oxford University Press.

Pettersson, F., Söderholm, P., 2009. The diffusion of renewable electricity in the presence of climate policy and technology learning: the case of Sweden. Renew. Sustain. Energy Rev. 13, 2031-2040.

Pinkse, J., Van den Buuse, D., 2012. The development and commercialization of solar PV technology in the oil industry. Energy Policy 40, 11-20.

Richstein, J.C., Chappin, É.J., de Vries, L.J., 2015. Adjusting the CO2 cap to subsidised RES generation: can CO2 prices be decoupled from renewable policy? Appl. Energ. 156, 693-702.

Rindova, V.P., Kotha, S., 2001. Continuous morphing: competing through dynamic capabilities, form, and function. Acad. Manage. J. 44, 1263-1280.

Rothaermel, F.T., Deeds, D.L., 2006. Alliance type, alliance experience and alliance management capability in high-technology ventures. J. Bus. Venturing $21,429-460$

Schmidt, T.S., Schneider, M., Hoffmann, V.H., 2012. Decarbonising the power sector via technological change-differing contributions from heterogeneous firms. Energy Policy 43, 466-479.

Schumpeter, J.A., 1942. Socialism, Capitalism and Democracy. Harper and Brothers.

Smink, M.M., Hekkert, M.P., Negro, S.O., 2015. Keeping sustainable innovation on a leash? Exploring incumbents' institutional strategies. Bus. Strat. Environ. 24, 86-101.

Teece, D.J., Pisano, G., Shuen, A., 1997. Dynamic capabilities and strategic management. Strat. Manage. 18, $509-533$.

Teece, D.J., 2007. Explicating Dynamic Capabilities: the nature and microfoundations of (sustainable) enterprise performance. Strat. Manage. J. 28, 1319-1350.

Ucbasaran, D., Westhead, P., Wright, M., 2009. The extent and nature of opportunity identification by experienced entrepreneurs. J. Bus. Venturing 24, $99-115$.

van der Vleuten, E., Raven, R., 2006. Lock-in and change: distributed generation in Denmark in a long-term perspective. Energy policy 34, 3739-3748.

Verbong, G.P., Geels, F.W., 2010. Exploring sustainability transitions in the electricity sector with socio-technical pathways. Technol. Forecast. Social Change 77, 1214-1221.

Vergne, J.-P., Durand, R., 2011. The path of most persistence: an evolutionary perspective on path dependence and dynamic capabilities. Org. Stud. 32, 365-382.

Wüstenhagen, R., Menichetti, E., 2012. Strategic choices for renewable energy investment: conceptual framework and opportunities for further research. Energy Policy 40, 1-10. 
Worch, H., Truffer, B., Kabinga, M., Eberhard, A., Markard, J., 2013. A capability perspective on performance deficiencies in utility firms. Utilities Policy 25, $1-9$.

Zahra, S.A., Nielsen, A.P., 2002. Sources of capabilities, integration and technology commercialization. Strat. Manage. J. 23, 377-398.

Zahra, S.A., Sapienza, H.J., Davidsson, P., 2006. Entrepreneurship and dynamic capabilities: a review, model and research agenda*. J. Manage. Stud. 43 , 917-955.

Zollo, M., Winter, S.G., 2002. Deliberate learning and the evolution of dynamic capabilities. Org. Sci. 13, 339-351. 